\title{
Front Matter: Volume 7798
}

, "Front Matter: Volume 7798," Proc. SPIE 7798, Applications of Digital Image Processing XXXIII, 779801 (27 September 2010); doi: 10.1117/12.879954

SPIE Event: SPIE Optical Engineering + Applications, 2010, San Diego, California, SPIE. United States 


\title{
PROCEEDINGS OF SPIE
}

\section{Applications of Digital Image Processing XXXIII}

\author{
Andrew G. Tescher
}

Editor

2-4 August 2010

San Diego, California, United States

Sponsored and Published by

SPIE

Volume 7798 
The papers included in this volume were part of the technical conference cited on the cover and title page. Papers were selected and subject to review by the editors and conference program committee. Some conference presentations may not be available for publication. The papers published in these proceedings reflect the work and thoughts of the authors and are published herein as submitted. The publisher is not responsible for the validity of the information or for any outcomes resulting from reliance thereon.

Please use the following format to cite material from this book:

Author(s), "Title of Paper," in Applications of Digital Image Processing XXXIII, edited by Andrew G. Tescher, Proceedings of SPIE Vol. 7798 (SPIE, Bellingham, WA, 2010) Article CID Number.

ISSN 0277-786X

ISBN 9780819482945

Published by

SPIE

P.O. Box 10, Bellingham, Washington 98227-0010 USA

Telephone +1 3606763290 (Pacific Time) · Fax +1 3606471445

SPIE.org

\section{Copyright (C) 2010, Society of Photo-Optical Instrumentation Engineers}

Copying of material in this book for internal or personal use, or for the internal or personal use of specific clients, beyond the fair use provisions granted by the U.S. Copyright Law is authorized by SPIE subject to payment of copying fees. The Transactional Reporting Service base fee for this volume is $\$ 18.00$ per article (or portion thereof), which should be paid directly to the Copyright Clearance Center (CCC), 222 Rosewood Drive, Danvers, MA 01923. Payment may also be made electronically through CCC Online at copyright.com. Other copying for republication, resale, advertising or promotion, or any form of systematic or multiple reproduction of any material in this book is prohibited except with permission in writing from the publisher. The CCC fee code is 0277-786X/10/\$18.00.

Printed in the United States of America.

Publication of record for individual papers is online in the SPIE Digital Library.

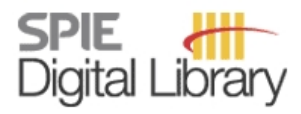

SPIEDigitalLibrary.org

Paper Numbering: Proceedings of SPIE follow an e-First publication model, with papers published first online and then in print and on CD-ROM. Papers are published as they are submitted and meet publication criteria. A unique, consistent, permanent citation identifier (CID) number is assigned to each article at the time of the first publication. Utilization of CIDs allows articles to be fully citable as soon they are published online, and connects the same identifier to all online, print, and electronic versions of the publication. SPIE uses a six-digit CID article numbering system in which:

- The first four digits correspond to the SPIE volume number.

- The last two digits indicate publication order within the volume using a Base 36 numbering system employing both numerals and letters. These two-number sets start with $00,01,02,03,04$, $05,06,07,08,09,0 A, 0 B \ldots 0 Z$, followed by 10-1Z, 20-2Z, etc.

The CID number appears on each page of the manuscript. The complete citation is used on the first page, and an abbreviated version on subsequent pages. Numbers in the index correspond to the last two digits of the six-digit CID number. 


\section{Contents}

xi Conference Committee

SESSION 1 IMAGE SIGNAL PROCESSING I

779805 Multi-scale edge detection with local noise estimate [7798-04]

B. Jiang, Old Dominion Univ. (United States); Z. Rahman, NASA Langley Research Ctr. (United States)

779806 Correlation filter design using a single cluttered training image for detecting a noisy target in a nonoverlapping scene [7798-05]

P. M. Aguilar-González, V. Kober, Ctr. de Investigación Científica y de Educación Superior de Ensenada (Mexico)

779807 Denoising point clouds using pulling-back method [7798-06]

C. Shen, East China Normal Univ. (China); Y. Peng, Shanghai Univ. (China); G. Zhang, East

China Normal Univ. (China)

\section{SESSION 2 IMAGE SIGNAL PROCESSING II}

779809 Image restoration based on multiple PSF information with applications to phase-coded imaging system [7798-08]

P.-C. Chen, Y.-L. Chen, H.-Y. Sung, Industrial Technology Research Institute (Taiwan)

7798 OA Motion-compensated compressed sensing for dynamic imaging [7798-09]

R. Sundaresan, Y. Kim, The Univ. of Arizona (United States); M. S. Nadar, Siemens Corporate Research (United States); A. Bilgin, The Univ. of Arizona (United States)

7798 OB Using enhancement data to deinterlace 1080i HDTV [7798-10]

A. L. Lin, Stanford Univ. (United States); J. S. Lim, Massachusetts Institute of Technology

(United States)

\section{SESSION 3 IMAGE SIGNAL PROCESSING III}

7798 OC Multispectral MRI-based virtual cystoscopy [7798-11]

L. Li, City Univ. of New York (United States); H. Zhu, S. Wang, Stony Brook Univ. (United States);

$X$. Wei, City Univ. of New York (United States); Z. Liang, Stony Brook Univ. (United States)

7798 OD Computational architecture for image processing on a small unmanned ground vehicle [7798-12]

S. Ho, H. Nguyen, U.S. Army Research Lab. (United States)

$7798 \mathrm{OE} \quad$ Automatic activity estimation based on object behaviour signature [7798-13]

F. E. Martínez-Pérez, J. A. González-Fraga, M. Tentori, Univ. Autónoma de Baja California (Mexico) 
7798 OG Signal processing and analyzing works of art [7798-15]

D. H. Johnson, Rice Univ. (United States); C. R. Johnson, Jr., Cornell Univ. (United States);

E. Hendriks, Van Gogh Museum (Netherlands)

$7798 \mathrm{OH} \quad$ Texton-based analysis of paintings [7798-16]

L. J. P. van der Maaten, Univ. of California, San Diego (United States) and Delft Univ. of Technology (Netherlands); E. O. Postma, Tilburg Univ. (Netherlands)

7798 Ol Multispectral imaging for digital painting analysis: a Gauguin case study [7798-17]

B. Cornelis, A. Dooms, Vrije Univ. Brussel (Belgium); F. Leen, Royal Museums of Fine-Arts

(Belgium); A. Munteanu, P. Schelkens, Vrije Univ. Brussel (Belgium)

$7798 \mathrm{0J}$ Attenuating hue identification and color estimation for underpainting reconstruction from x-ray synchrotron imaging data [7798-18]

A. Anitha, S. M. Hughes, Univ. of Colorado at Boulder (United States)

\section{SESSION 5 VISUAL SEARCH I}

7798 OK Keypoint clustering for robust image matching [7798-19]

S. Vaddadi, O. Hamsici, Y. Reznik, J. Hong, C. Lee, Qualcomm Inc. (United States)

$7798 \mathrm{OL} \quad$ Fast quantization and matching of histogram-based image features [7798-20]

Y. A. Reznik, Qualcomm Inc. (United States); V. Chandrasekhar, G. Takacs, D. M. Chen,

S. S. Tsai, B. Girod, Stanford Univ. (United States)

7798 OM Permutable descriptors for orientation-invariant image matching [7798-21]

G. Takacs, V. Chandrasekhar, H. Chen, D. Chen, S. Tsai, Stanford Univ. (United States);

R. Grzeszczuk, Nokia Research Ctr. (United States); B. Girod, Stanford Univ. (United States)

779800 Object tracking in real environments [7798-23]

A. M. Nelson, J. J. Neubert, The Univ. of North Dakota (United States)

\section{SESSION 6 VISUAL SEARCH II}

7798 OP Three-dimensional target modeling with synthetic aperture radar [7798-24]

J. R. Hupton, J. A. Saghri, California Polytechnic State Univ., San Luis Obispo (United States)

$7798 \mathrm{OQ}$ A Bayesian network-based approach for identifying regions of interest utilizing global image features [7798-25]

M. Jaber, E. Saber, Rochester Institute of Technology (United States)

7798 OR Low-cost asset tracking using location-aware camera phones [7798-26]

D. Chen, S. Tsai, Stanford Univ. (United States); K.-H. Kim, C.-H. Hsu, J. P. Singh, Deutsche

Telekom Inc. (United States); B. Girod, Stanford Univ. (United States)

7798 OS Propagation of geotags based on object duplicate detection [7798-27]

P. Vajda, I. Ivanov, J.-S. Lee, L. Goldmann, T. Ebrahimi, Ecole Polytechnique Fédérale de Lausanne (Switzerland) 
7798 OU Design of high-performance fixed-point transforms using the common factor method [7798-29]

A. T. Hinds, Ricoh InfoPrint Solutions Co. (United States)

7798 OV Recent developments in standardization of high efficiency video coding (HEVC) [7798-30] G. J. Sullivan, Microsoft Corp. (United States); J.-R. Ohm, RWTH Aachen (Germany)

7798 OW Efficient large size transforms for high-performance video coding [7798-31]

R. Joshi, Y. A. Reznik, M. Karczewicz, Qualcomm Inc. (United States)

\section{SESSION 8 COMPRESSION AND TRANSFORMS FOR IMAGES AND VIDEO II}

7798 OX Low-complexity lossless codes for image and video coding [7798-32]

Y. A. Reznik, Qualcomm Inc. (United States)

7798 OY Embedded memory compression for video and graphics applications [7798-33]

A. Teng, D. Gokce, M. Aleksic, Y. A. Reznik, Qualcomm Inc. (United States)

$7798 \mathrm{OZ}$ Self-derivation of motion estimation techniques to improve video coding efficiency [7798-34]

Y. Chiv, Intel Corp. (United States); L. Xu, W. Zhang, Intel Labs. China (China); H. Jiang, Intel Corp. (United States)

$779810 \quad$ Variable length coding for binary sources and applications in video compression [7798-35]

G. Korodi, D. He, P. Imthurn, Research In Motion Ltd. (Canada)

779811 Subjective evaluation of next-generation video compression algorithms: a case study [7798-36]

F. De Simone, L. Goldmann, J.-S. Lee, T. Ebrahimi, Ecole Polytechnique Fédérale de Lausanne (Switzerland); V. Baroncini, Fondazione Ugo Bordoni (Italy)

\section{SESSION 9 COMPUTATIONAL IMAGING I: JOINT SESSION WITH CONFERENCE 7800}

779812 High dynamic range video with ghost removal [7798-37]

S. Mangiat, J. Gibson, Univ. of California, Santa Barbara (United States)

779813 ECME hard thresholding methods for image reconstruction from compressive samples [7798-38]

K. Qiu, A. Dogandžić, lowa State Univ. (United States)

779814 A survey of image retargeting techniques [7798-39]

D. Vaquero, M. Turk, Univ. of California, Santa Barbara (United States); K. Pulli, M. Tico,

N. Gelfand, Nokia Research Ctr. (United States)

779815 Objective and subjective measurement and modeling of image quality: a case study [7798-40]

B. W. Keelan, Aptina, LLC (United States) 
779816 Computationally efficient deblurring of shift-variant highly defocused images [7798-41]

S. B. Sastry, M. Subbarao, Stony Brook Univ. (United States)

SESSION 10 COMPUTATIONAL IMAGING II: JOINT SESSION WITH CONFERENCE 7800

779817 The restoration of large blur image based on POCS algorithm [7798-42]

J. Luo, Huazhong Univ. of Science and Technology (China) and Huazhong Agricultural Univ.

(China); X. Zhang, C. Xie, T. Zhang, Huazhong Univ. of Science and Technology (China)

779818 Generating highly realistic 3D animation video with depth-of-field and motion blur effects [7798-43]

K. Sathyanarayana, M. Subbarao, Stony Brook Univ. (United States)

SESSION 11 PERCEPTUAL CODING OF STILL AND MOTION IMAGES I

7798 1C Evaluation of MPEG4-SVC for QoE protection in the context of transmission errors [7798-46]

Y. Pitrey, M. Barkowsky, P. Le Callet, R. Pépion, Univ. de Nantes (France)

7798 ID Rate allocation as quality index performance test [7798-47]

T. Richter, Univ. Stuttgart (Germany)

7798 IE A compressive sensing approach to perceptual image coding [7798-48]

M. R. Pickering, Univ. of New South Wales (Australia); J. You, Norwegian Univ. of Science and Technology (Norway); T. Ebrahimi, Norwegian Univ. of Science and Technology (Norway) and Ecole Polytechnique Fédérale de Lausanne (Switzerland);

A. Perkis, Norwegian Univ. of Science and Technology (Norway)

SESSION 12 PERCEPTUAL CODING OF STILL AND MOTION IMAGES II

7798 IF Perceptually optimized quantization tables for H.264/AVC [7798-49]

H. Chen, G. Braeckman, J. Barbarien, A. Munteanu, P. Schelkens, Vrije Univ. Brussel (Belgium)

$77981 G$ Open source database of images DEIMOS: high dynamic range images [7798-50]

K. Fliegel, P. Páta, M. Klíma, M. Blažek, J. Havlín, Czech Technical Univ. in Prague (Czech

Republic)

$77981 \mathrm{H} \quad$ Research of color distribution index in CIE L*a*b* color space [7798-51]

W.-D. Jeng, National Chiao Tung Univ. (Taiwan); T.-W. Huang, National Central Univ.

(Taiwan); O.-Y. Mang, National Chiao Tung Univ. (Taiwan); T.-H. Lee, Wistron Corp. (Taiwan);

Y.-F. Hsieh, National Central Univ. (Taiwan); Y.-T. Kuo, National Chiao Tung Univ. (Taiwan)

and Jen-Teh Junior College of Medicine, Nursing and Management (Taiwan)

SESSION 13 MOBILE VIDEO: PROCESSING, COMMUNICATIONS, DISPLAY, AND APPLICATIONS I

$779811 \quad$ Video quality management for mobile video application [7798-52]

K.-C. Yang, K. El-Maleh, V. Bhaskaren, Qualcomm Inc. (United States) 
7798 IK Low-complexity H.264/AVC motion compensated prediction for mobile video applications [7798-54]

S.-W. Lee, C.-C. J. Kuo, The Univ. of Southern California (United States)

$77981 \mathrm{~L}$ Decoder friendly H.264/AVC deblocking filter design [7798-55]

S.-W. Lee, C.-C. J. Kuo, The Univ. of Southern California (United States)

SESSION 14 MOBILE VIDEO: PROCESSING, COMMUNICATIONS, DISPLAY, AND APPLICATIONS II

$77981 \mathrm{M} \quad$ Postprocessing and denoising of video using sparse multiresolutional transforms [7798-56]

O. G. Sezer, Georgia Tech (United States); O. G. Guleryuz, DoCoMo Communications Labs. USA, Inc. (United States)

7798 iN Image retargeting for small display devices [7798-57]

C. Jung, C. Kim, Korea Advanced Institute of Science and Technology (Korea, Republic of)

7798 1P Adaptive image backlight compensation for mobile phone users [7798-59]

H. Kong, C. Jung, W. Kim, J. Lee, C. Kim, Korea Advanced Institute of Science and Technology (Korea, Republic of)

$77981 Q \quad$ Remote gaming on resource-constrained devices [7798-60]

W. Reza, H. Kalva, R. Kaufman, Florida Atlantic Univ. (United States)

SESSION 15 OPTICS, PHOTONICS AND DIGITAL IMAGE PROCESSING

7798 IR Multivariate image analysis of laser-induced photothermal imaging used for detection of caries tooth [7798-61]

A. F. El-Sherif, W. M. Abdel Aziz, Y. H. El-Sharkawy, Egyptian Armed Forces (Egypt)

7798 is A multi-pedestrian detection and counting system using fusion of stereo camera and laser scanner [7798-62]

B. Ling, S. Tiwari, Z. Li, Migma Systems, Inc. (United States); D. R. P. Gibson, Federal Highway Administration (United States)

7798 1T Defect detection and classification of machined surfaces under multiple illuminant directions [7798-63]

Y. Liao, X. Weng, Univ. of Michigan (United States); C. W. Swonger, Coherix Inc. (United

States); J. Ni, Univ. of Michigan (United States)

$77981 \mathrm{U}$ Comparison between two different methods to obtain the wavefront aberration function [7798-64]

A. S. Cruz Félix, J. Ibarra, E. López, Instituto Nacional de Astrofísica, Óptica y Electrónica (Mexico); M. A. Rosales, Univ. de las Américas Puebla (Mexico); E. Tepichín, Instituto Nacional de Astrofísica, Óptica y Electrónica (Mexico)

7798 1V Refractive power maps of the anterior surface of the cornea according to different models [7798-65]

L. Morales-Tellez, M. A. Rosales, Univ. de las Américas Puebla (Mexico); E. López-Olazagasti, G. Ramírez-Zavaleta, E. Tepichín, Instituto Nacional de Astrofísica, Óptica y Electrónica (Mexico) 
7798 IW Rapid ideal template creation for the inspection of MEMS based on self-similarity characteristics [7798-66]

A. Burla, T. Haist, W. Lyda, A. Y. Michael, W. Osten, Univ. Stuttgart (Germany)

7798 1Y Automatic alignment of multi-temporal images of planetary nebulae using local optimization [7798-68]

F. Kazemzadeh, A. R. Hajian, Univ. of Waterloo (Canada)

POSTER SESSION

779820 The development of an automatic scanning path generation method for the spinneret test [7798-70]

C.-J. Chen, M.-W. Hung, W. Jywe, D. Chiang, Instrument Technology Research Ctr. (Taiwan)

779821 Meteor automatic imager and analyzer: analysis of noise characteristics and possible noise suppression [7798-71]

J. Švihlík, Institute of Chemical Technology (Czech Republic); K. Fliegel, P. Páta, S. Vítek, Czech Technical Univ. in Prague (Czech Republic); P. Koten, Academy of Sciences of the Czech Republic (Czech Republic)

779822 Correlation-based nonlinear composite filters applied to image recognition [7798-72] S. Martínez-Díaz, Instituto Tecnológico de La Paz (Mexico)

779823 Automated tracking of yeast cell lineages [7798-73]

K. Kim, HRL Labs., LLC (United States); A. C. Rowat, Harvard Univ. (United States);

A. E. Carpenter, Broad Institute of MIT and Harvard (United States)

779824 Center location error correction of circular targets [7798-74]

Y. Yin, Tianjin Univ. (China); X. Liu, A. Li, C. Zhang, D. He, Shenzhen Univ. (China); X. Peng,

Tianjin Univ. (China) and Shenzhen Univ. (China)

779825 Performance of visual tasks from contour information [7798-75]

Y. Yitzhaky, L. Itan, Ben-Gurion Univ. of the Negev (Israel)

779826 Augmented reality system [7798-76]

C.-L. Lin, Y.-Z. SU, M.-W. Hung, K.-C. Huang, Instrument Technology Research Ctr. (Taiwan)

779827 Image restoration with local adaptive methods [7798-77]

C. A. Carranza, V. Kober, H. Hidalgo, Ctr. de Investigación Científica y de Educación Superior de Ensenada (Mexico)

779829 Improvement of visual perception in cloudy environments [7798-79]

F. J. Arias, V. H. Diaz-Ramirez, Ctr. de Investigación y Desarrollo de Tecnología Digital (Mexico)

7798 2A Performance test of optical and electronic image stabilizer for digital imaging system [7798-80]

Q. Li, Z. XU, H. Feng, Y. Chen, Zhejiang Univ. (China) 
7798 2B Meteor automatic imager and analyzer: system design and its parameters [7798-81] K. Fliegel, P. Páta, S. Vítek, Czech Technical Univ. in Prague (Czech Republic); P. Koten, Academy of Sciences of the Czech Republic (Czech Republic)

7798 2C Analysis of the selection of overlapping region of sectioned restoration for images with space-variant point spread function [7798-82]

X. Tao, J. Zhao, H. Feng, Q. Li, Z. Xu, Y. Chen, Zhejiang Univ. (China)

7798 2D Image restoration of nonuniformly illuminated images with camera microscanning [7798-83] J. L. López-Martínez, Ctr. de Investigación Científica y de Educación Superior de Ensenada (Mexico) and Univ. Autómata de Yucatán (Mexico); V. Kober, Ctr. de Investigación Científica y de Educación Superior de Ensenada (Mexico)

7798 2E Vertex-based marching algorithms for finding multidimensional geometric intersections [7798-84]

L. T. Dechevsky, A. Lakså, B. Bang, J. Gundersen, A. R. Kristoffersen, P. Zanaty, Narvik Univ. College (Norway)

7798 2F Calibration of a dual-PTZ camera system for stereo vision [7798-85]

Y.-Z. Chang, J.-F. Hou, Y. H. Tsao, Chang Gung Univ. (Taiwan); S.-T. Lee, Chang Gung Memorial Hospital (Taiwan)

$77982 \mathrm{H} \quad$ Utilization of consumer level digital cameras in astronomy [7798-87]

P. Páta, K. Fliegel, M. Klíma, M. Blažek, M. Řeřábek, Czech Technical Univ. in Prague (Czech Republic)

$779821 \quad$ Use of the EM algorithm in image registration in a scene captured by a moving camera [7798-88]

N. M. Namazi, The Catholic Univ. of America (United States); W. Scharpf, U.S. Naval Research Lab. (United States); J. Obermark, DCS Corp. (United States); J. N. Caron, Research Support Instruments, Inc. (United States)

7798 2J Scene kinetics mitigation using factor analysis with derivative factors [7798-90] D. K. Melgaard, A. J. Scholand, K. W. Larson, Sandia National Labs. (United States)

$77982 \mathrm{~L} \quad$ Novel gray coded pattern for unwrapping phase in fringe projection based 3D profiling [7798-93]

M. Kondiparthi, A. Phani, Indian Institute of Science (India)

$77982 \mathrm{M}$

A comparison between intensity and depth images for extracting features related to wear labels in carpets [7798-94]

S. A. Orjuela, E. Vansteenkiste, F. Rooms, S. De Meulemeester, R. de Keyser, W. Philips, Univ. Gent (Belgium)

Author Index 
Downloaded From: https://www.spiedigitallibrary.org/conference-proceedings-of-spie on 26 Apr 2023

Terms of Use: https://www.spiedigitallibrary.org/terms-of-use 


\title{
Conference Committee
}

\author{
Program Track Chair
}

Khan M. Iftekharuddin, The University of Memphis (United States)

Conference Chair

Andrew G. Tescher, AGT Associates (United States)

Program Committee

Vasudev Bhaskaran, Qualcomm Inc. (United States)

Bernard V. Brower, ITT Corporation (United States)

Wo L. Chang, National Institute of Standards and Technology (United States)

Touradj Ebrahimi, Ecole Polytechnique Fédérale de Lausanne (Switzerland)

Ali Habibi, InfoPrint Solutions Company (United States)

Arianne T. Hinds, InfoPrint Solutions Company (United States)

T. Russell Hsing, Telcordia Technologies, Inc. (United States)

Kristina M. Johnson, U.S. Department of Energy (United States)

C.-C. Jay Kuo, The University of Southern California (United States)

Catherine Lambert-Nebout, Centre National d'Études Spatiales (France)

Dan Lelescu, Pelican Imaging Corporation (United States)

Andre J. Oosterlinck, Kuleuven R \& D (Belgium)

Sethuraman Panchanathan, Arizona State University (United States)

Fernando Pereira, Instituto Superior Técnico (Portugal)

Yuriy A. Reznik, Qualcomm Inc. (United States)

Thomas Richter, Universität Stuttgart (Germany)

John A. Saghri, California Polytechnic State University, San Luis Obispo (United States)

Peter Schelkens, Vrije Universiteit Brussel (Belgium)

Gary J. Sullivan, Microsoft Corporation (United States)

Pankaj Topiwala, FastVDO Inc. (United States)

Mihaela van der Schaar, University of California, Los Angeles (United States)

Anthony Vetro, Mitsubishi Electric Research Laboratory (United States) 
Session Chairs

$1 \quad$ Image Signal Processing I

Touradj Ebrahimi, Ecole Polytechnique Fédérale de Lausanne (Switzerland)

2 Image Signal Processing II

Touradj Ebrahimi, Ecole Polytechnique Fédérale de Lausanne (Switzerland)

3 Image Signal Processing III

Touradj Ebrahimi, Ecole Polytechnique Fédérale de Lausanne (Switzerland)

4 Digital Cultural Heritage

Peter Schelkens, Vrije Universiteit Brussel (Belgium)

5 Visual Search I

Yuriy A. Reznik, Qualcomm Inc. (United States)

6 Visual Search II

Yuriy A. Reznik, Qualcomm Inc. (United States)

7 Compression and Transforms for Images and Video I

Gary J. Sullivan, Microsoft Corporation (United States)

Anthony Vetro, Mitsubishi Electric Research Laboratory (United States)

8 Compression and Transforms for Images and Video II

Francesca De Simone, Ecole Polytechnique Fédérale de Lausanne (Switzerland))

9 Computational Imaging I: Joint Session with Conference 7800

Dan Lelescu, Pelican Imaging Corporation (United States)

10 Computational Imaging II: Joint Session with Conference 7800

Lazar M. Bivolarski, Consultant (United States)

11 Perceptual Coding of Still and Motion Images I

Thomas Richter, Universität Stuttgart (Germany)

12 Perceptual Coding of Still and Motion Images II

Thomas Richter, Universität Stuttgart (Germany)

13 Mobile Video: Processing, Communications, Display, and

Applications I

Vasudev Bhaskaran, Qualcomm Inc. (United States) 
14 Mobile Video: Processing, Communications, Display, and Applications II

Vasudev Bhaskaran, Qualcomm Inc. (United States)

15 Optics, Photonics and Digital Image Processing

Peter Schelkens, Vrije Universiteit Brussel (Belgium) 
Downloaded From: https://www.spiedigitallibrary.org/conference-proceedings-of-spie on 26 Apr 2023

Terms of Use: https://www.spiedigitallibrary.org/terms-of-use 